\title{
Historiography of Mosque Architecture in Malaysia: Analysis of Texts by 5 Authors
}

\author{
Megat Ariff Shah, Ezrin Arbi \& Nila Keumala \\ Department of Architecture, Faculty of Built Environment, University of Malaya, Kuala Lumpur, \\ Malaysia \\ *megatariffshah@gmail.com
}

\begin{abstract}
Malaysian mosques exhibit remarkable variations, ranging from humble traditional timber structures to massive modern complexes. This evolution has been studied by numerous historians, architects, and academicians resulting in a steadily expanding historiography of mosque architecture. However, this body of work on the history and development of local mosques has never been formally studied in detail as a whole. Therefore, this paper focuses on 2 major aspects: first, identifying general research approaches present in the historiography of mosque architecture in Malaysia, and second, classifying the formal elements and characteristics used to describe the architecture of local mosques. Based on selected texts from 5 Malaysian authors, it was identified that these works are descriptive studies that are primarily structured on a combination of chronological, stylistic, cultural, geographical and typological approaches. Additionally, descriptions of mosque architecture by the authors were based on a set of formal elements and characteristics which falls into 5 distinct categories: i) typological element, ii) spatial organisation, iii) roof form, iv) building technology, and v) design articulation. These results reflect the complexity of mosque development in Malaysia and the multiple angles that are possible to holistically examine them. This paper also discusses 3 significant aspects embedded within the study of mosque architecture in Malaysia, covering unique elements and characteristics of local mosques, followed by issues related to language, conceptual, and factual ambiguity, and finally on the complexity of mosque classifications.
\end{abstract}

Keywords: Mosque Architecture, Historiography, Elements, Characteristics.

\section{INTRODUCTION}

In Malaysia, scholarship on mosque architecture and its development can be found in the field of architectural theory, architectural history, Malay culture, Islamic studies, art history, and Malaysian history. At the outset, there are limited early Malay literatures that referenced mosques or Muslim architecture. However, 2 works are generally viewed as important semi-historical accounts, namely the Malay Annals (Sejarah Melayu or Sulalatus Salatin) that made multiple references to mosques as well as architectural elements such as verandas, halls, and palaces, and the Kedah Annals (Hikayat Merong Mahawangsa) that narrated the arrival of Islam in the state of Kedah and gave clues to the existence of mosques which could be as early as the tenth or eleventh centuries (Abdul Halim, 1984a; Alice Sabrina, 2008; Bruce, 1996). However, these provided little details on the general designs of mosques. This lack of documentation of early mosques is problematic since extant historical mosques in the Malay Peninsula can be identified only as far back as the early eighteenth century, of which very few currently exists. Although the earliest tangible evidence of the presence of Islam in the Malay Peninsula is the Terengganu Stone (Batu Bersurat Terengganu) - inscribed with the year 1303 - there are no identifiable remnant of mosque architecture that stretches back to that period (A. Ghafar, 1999; Abdul Halim, 2004).

In the early sixteenth century Tomé Pires documented the siege of Melaka by the Portuguese. In it, Pires briefly mentioned a mosque built by Megat Iskandar Shah who ruled Melaka in the midfifteenth century circa 1459-1477 (Cortesão, 2005). A large gap on literature referencing local mosques ensued until the eighteenth century, when active involvement of the British in the Malay Peninsula resulted in a number of textual and visual references to mosque architecture such as informal observations, sketches, watercolours and photographs of mosques. There were also reports and documentation on mosque building activities by the Public Works Department, local newspapers and 
journals. By the time of Malaysia's independence in 1957, articles on the architecture of the Malayan Union by British-trained architects appeared in PETA, the official journal of the Federation of Malaya Society of Architects (FMSA). Similarly, historical and cultural interests were addressed by the Journal of the Straits Branch of the Royal Asiatic Society (JSBRAS) - first published in 1978 - and proved to be invaluable for their broad focus on art, culture, history, and architecture. However, these journal articles leaned toward commentaries on either specific mosques or brief mentions of mosques within more general observations on local architecture. Nevertheless, this period helped to formally identify mosques as a significant building type within traditional Malay architectural typology.

Eventually, the ongoing discourse on traditional Malay architecture was elevated to national-level platforms and marked by 2 notable events; the National Culture Congress (Kongres Kebudayaan Kebangsaan) in 1971 and the follow-up Seminar on National Identity in Architecture (Seminar Kearah Identiti Kebangsaan Dalam Senibina) in 1981. These events reported on the increasing efforts to document and research traditional architecture, most of which were conducted by the National Archive, National Library, and Ministry of Culture, Youth and Sports of Malaysia, as well as the University of Technology, Malaysia (UTM) and the MARA Institute of Technology (now UiTM) (Zakiah Hanum, 1981). It was during this early postindependence period that documentation on local mosques also accompanied conservation efforts, such as on the historic Kampung Laut Mosque in Kelantan which was undertaken by the Malayan Historical Society and the National Museums Department.

Currently, studies on mosque architecture exhibit more formal and critical inquiries. These expanded earlier works which mostly focused on documenting existing mosque architecture and the overall history and development of mosques. Some of these current studies focused on specific mosque components such as the mihrab (Rosniza, 2011) or spatial arrangement (Rosniza, Nila, \& Yahaya, 2008). Others focused on broader issues related to ideological or cultural concerns using examples of iconic mosques (Alice Sabrina, 2008), Melaka style traditional mosques (Armani, 2014), or early mosques of Peninsular Malaysia (Bruce, 1996).
Hence, considering the sustained and increased interests in the history and development of mosque architecture, as evidenced by the number of publications related to Malaysian mosques within the past 50 years, it would be timely to take a closer look at these historiographical works. On the whole, there are diverse narratives and findings that are the result of different perspectives of the respective authors. Furthermore, the limited number of pioneering works on the subject matter meant that multiple references to the same works and/or authors frequently occurred, regardless of the original author's research approaches. Therefore, this paper proposed that research approaches, in conjunction with formal design elements and characteristics, are 2 of the most significant aspects that helped define existing historiographical work on mosque architecture in Malaysia.

\section{METHODOLOGY}

The investigation began with a selection of texts on the history and development of Malaysian mosque architecture, resulting in an initial list of 50 texts. These comprised journal and conference papers (22\%), newspaper and magazine articles (8\%), books or chapters in books $(56 \%)$, and Masters and $\mathrm{PhD}$ dissertations (14\%). Resourced via libraries and online academic archives, these ranged from international authors such as Al-Faruqi and AlFaruqi (1986) and Frishman and Khan (2007), as well as by regional or local authors (which formed the majority of selected works) such as Abdullah (1978), Vlatseas (1990), and Yulianto (2000). The selection was then shortlisted to 7 texts written by 5 Malaysian authors, which are A. Ghafar Ahmad, Abdul Halim Nasir, David Mizan Hashim, Ken Yeang, and Mohamad Tajuddin Mohamad Rasdi. These were selected for the following reasons: first, they presented the architectural history of mosques in Malaysia in a holistic manner by covering a range of mosques from early to modern, together with the overall design of mosques rather than specific components; second, the works and/or authors were often, if not consistently, referenced in other studies on Malaysian architecture or mosque architecture; and third, they significantly contributed to the diversity of scholarships on the subject matter, hence enabling well-rounded and richer analyses and discussions.

The first step was to determine the research approaches present in the sampled texts, specifically 
related to the aims and outcomes. Next, an index of formal elements and characteristics of mosque architecture was established. Finally, a discussion of substantial aspects found in these texts, and the likely impact they might have on the larger historiography of mosque architecture in Malaysia, was offered. It should be noted that 2 of the chosen authors wrote 4 out of the 7 selected texts; although they have some similarities, these 4 texts are significantly different works that add variety as well as enrich the findings.

\section{RESULTS}

\subsection{GENERAL RESEARCH APPROACH IN HISTORIOGRAPHY OF MOSQUE ARCHITECTURE IN MALAYSIA}

The selected texts presented the historical development of mosque architecture in Malaysia with specific aims and outcomes (see Table 1). All referred to early timber mosques of the Malay Peninsula and/or the Southeast Asia region, as well as mosques built during the colonial and modern periods. The majority of buildings mentioned in the texts are from the Malay Peninsula, which can be attributed to the large number of mosques with shared architectural and historical roots. These works vary in length - from concise encyclopedia entries (David Mizan, 1998a, 1998b, 1998c), to conference papers (A. Ghafar, 1999) and books (Yeang, 1992) - as well as written in either Malay (Abdul Halim, 1984a, 1995) or English. A significant point is that each text usually referred to the general architectural history of Malaysia and/or Southeast Asia in their narratives.

\subsubsection{Background of Authors}

The 5 authors are a combination of architects, historians and/or academicians. Almost all were trained as architects either in the UK or the USA, and are currently practising architects and/or academics based in Malaysia. The sole exception is the late Abdul Halim Nasir who was a historian specialising on Malay studies and was attached to the National Museum (1963-1988), and then the National University of Malaysia (UKM) as a visiting scholar or karyawan tamu (1989-1997). Out of the 5, A. Ghafar Ahmad, Ken Yeang and Mohamad Tajuddin Mohamad Rasdi completed their PhDs in the field of architecture focusing on conservation, sustainability, and theory and history respectively. David Mizan Hashim completed his Masters in architecture prior to an Aga Khan Travel Fellowship which focused on Malaysian mosques. Both David Mizan Hashim and Ken Yeang are registered professional architects.

Table 1: Comparison of selected texts by 5 Malaysian authors on the architectural history and development of Malaysian mosques

\begin{tabular}{|c|c|c|c|c|}
\hline No. & $\begin{array}{c}\text { Author (Editor). Title. } \\
\text { Year Published }\end{array}$ & Type of Work & Aim of Work & Outcome of Work \\
\hline 1 & $\begin{array}{l}\text { A. Ghafar Ahmad } \\
\text { The Architectural Styles } \\
\text { of Mosques in Malaysia: } \\
\text { From Vernacular to } \\
\text { Modern Structures. } 1999\end{array}$ & $\begin{array}{l}\text { Symposium paper: } \\
\text { Overview of } \\
\text { Malaysian mosques } \\
\text { and their design } \\
\text { transformation }\end{array}$ & $\begin{array}{l}\text { Comparative analysis } \\
\text { of Malaysian mosques } \\
\text { based on scale, } \\
\text { elements, materials, } \\
\text { ornamentation, } \\
\text { facilities and fixtures }\end{array}$ & $\begin{array}{l}\text { Division of mosque } \\
\text { into } 3 \text { styles of } \\
\text { vernacular, colonial } \\
\text { and modern and } \\
\text { their historical and } \\
\text { cultural } \\
\text { significance } \\
\end{array}$ \\
\hline \multirow[t]{2}{*}{2} & $\begin{array}{l}\text { Abdul Halim Nasir (Eds. } \\
\text { Mohd. Ridzuan Tumin \& } \\
\text { Ahmad Sebi Abu Bakar). } \\
\text { Masjid-masjid di } \\
\text { Semenanjung Malaysia. } \\
1984 \\
\text { Note: English edition } \\
\text { published same year. }\end{array}$ & $\begin{array}{l}\text { Accompanying } \\
\text { monograph to the } \\
\text { National Museum's } \\
\text { exhibition on Islam } \\
\text { Civilisation: } \\
\text { Earliest informal } \\
\text { inventory of } \\
\text { Malaysian mosques }\end{array}$ & $\begin{array}{l}\text { Overview of mosques } \\
\text { in Peninsular Malaysia } \\
\text { from a Malay ethno- } \\
\text { cultural perspective }\end{array}$ & $\begin{array}{l}\text { Grouping based on } \\
\text { traditional and non- } \\
\text { traditional roof } \\
\text { forms, } \\
\text { accompanied by } \\
\text { original } \\
\text { photographs and } \\
\text { drawings by the } \\
\text { author }\end{array}$ \\
\hline & $\begin{array}{l}\text { Abdul Halim Nasir } \\
\text { Seni Bina Masjid di } \\
\text { Dunia Melayu-Nusantara. } \\
1995\end{array}$ & $\begin{array}{c}\text { Book on Indo- } \\
\text { Malaysian } \\
\text { Archipelagic } \\
\text { mosques: Emphasis } \\
\text { on } \\
\end{array}$ & $\begin{array}{c}\text { Identification of } \\
\text { variations of mosques } \\
\text { in the Indo-Malaysian } \\
\text { Archipelago }\end{array}$ & $\begin{array}{l}\text { Classification } \\
\text { based on roof } \\
\text { forms: pitched, } \\
\text { domed and modern } \\
\text { roof varieties. } \\
\end{array}$ \\
\hline
\end{tabular}




\begin{tabular}{|c|c|c|c|c|}
\hline & $\begin{array}{l}\text { Note: English translation } \\
\text { published in } 2004 \text {. }\end{array}$ & $\begin{array}{l}\text { Malaysian mosques } \\
\text { approached from a } \\
\text { geo-cultural aspect }\end{array}$ & & $\begin{array}{l}\text { Explanation of } \\
\text { components } \\
\text { associated with } \\
\text { mosques in the } \\
\text { Indo-Malaysian } \\
\text { Archipelagic region }\end{array}$ \\
\hline \multirow[t]{2}{*}{3} & $\begin{array}{l}\text { David Mizan Hashim } \\
\text { Typology and the } \\
\text { Evolution of the } \\
\text { Malaysian Mosque. } \\
\text { Nov/Dec } 1990\end{array}$ & $\begin{array}{l}\text { Article in Majalah } \\
\text { Arkitek: Proposed } \\
\text { a typological } \\
\text { approach to study } \\
\text { Malaysian mosque } \\
\text { architecture }\end{array}$ & $\begin{array}{l}\text { Exploration of } \\
\text { mosques as a building } \\
\text { type in response to } \\
\text { historical pastiche } \\
\text { trend in Malaysia }\end{array}$ & $\begin{array}{l}\text { Building type- } \\
\text { related observation } \\
\text { of mosque designs } \\
\text { based on planning, } \\
\text { materials, structure, } \\
\text { and ornamentations }\end{array}$ \\
\hline & $\begin{array}{l}\text { David Mizan Hashim } \\
\text { (Ed. Chen Voon Fee). i) } \\
\text { The Southeast Asian } \\
\text { Great Mosque, ii) Indian } \\
\text { and Mogul Influences on } \\
\text { Mosques, iii) Western and } \\
\text { Modernist Influences on } \\
\text { Mosques. } 1998\end{array}$ & $\begin{array}{c}\text { Entries in the } \\
\text { volume dedicated } \\
\text { to architecture from } \\
\text { The Encyclopedia } \\
\text { of Malaysia: Out of } \\
\text { a total of } 53 \text { entries, } \\
\text { only these } 3 \text { were } \\
\text { dedicated to } \\
\text { mosques }\end{array}$ & $\begin{array}{l}\text { Summary of mosque } \\
\text { history in Malaysia, } \\
\text { focusing on iconic or } \\
\text { historically significant } \\
\text { mosques }\end{array}$ & $\begin{array}{c}\text { Division of mosque } \\
\text { into } 3 \text { styles: } \\
\text { Southeast Asian, } \\
\text { Mogul, and } \\
\text { Western / } \\
\text { Modernist. } \\
\text { Highlighting } \\
\text { overlaps or } \\
\text { transition between } \\
\text { the styles }\end{array}$ \\
\hline 4 & $\begin{array}{l}\text { Ken Yeang } \\
\text { The Architecture of } \\
\text { Malaysia. } 1992\end{array}$ & $\begin{array}{l}\text { Book on Malaysian } \\
\text { architectural } \\
\text { history: Mosques } \\
\text { treated as an } \\
\text { important building } \\
\text { type }\end{array}$ & $\begin{array}{c}\text { Overview of Malaysian } \\
\text { architectural } \\
\text { development and the } \\
\text { influence of socio- } \\
\text { economic contexts }\end{array}$ & $\begin{array}{c}\text { Overview of } \\
\text { history of } \\
\text { architecture in } \\
\text { Malaysia with } \\
\text { numerous historical } \\
\text { and current } \\
\text { photographs to } \\
\text { highlight different } \\
\text { styles }\end{array}$ \\
\hline 5 & $\begin{array}{l}\text { Mohamad Tajuddin } \\
\text { Mohamad Rasdi } \\
\text { Mosque Architecture in } \\
\text { Malaysia: Classification } \\
\text { of Styles and Possible } \\
\text { Influence. } 2007\end{array}$ & $\begin{array}{l}\text { Journal paper: } \\
\text { Critical } \\
\text { commentary on the } \\
\text { classification of } \\
\text { mosques, with a } \\
\text { proposal to expand } \\
\text { the commonly used } \\
\text { division of } \\
\text { traditional, colonial } \\
\text { and modern styles }\end{array}$ & $\begin{array}{l}\text { Identification of } \\
\text { Malaysian mosque } \\
\text { styles to expand } \\
\text { existing categories to } \\
\text { include those } \\
\text { previously overlooked } \\
\text { or subsumed into other } \\
\text { stylistic categories }\end{array}$ & $\begin{array}{l}\text { Classification into } \\
7 \text { distinct styles and } \\
\text { accompanying sub- } \\
\text { styles: Traditional } \\
\text { Vernacular, Sino- } \\
\text { Eclectic, European } \\
\text { Classical, North } \\
\text { Indian, Modern } \\
\text { Vernacular, } \\
\text { Modernistic and } \\
\text { Post Modern } \\
\text { Revivalism. } \\
\text { Mosque as a } \\
\text { reflection of } \\
\text { cultural, ideological } \\
\text { and socio-political } \\
\text { influences }\end{array}$ \\
\hline
\end{tabular}

\subsubsection{Type of Work}

The 5 authors produced a variety of work, ranging from the earliest informal survey of the complete range of mosque designs in Malaysia (Abdul Halim, 1984a, 1984b), to inquiries on local mosque history within the larger development of Malaysian architecture (David Mizan, 1998a, 1998b, 1998c; Yeang, 1992), and critical appraisals of the formal classification of mosques (David Mizan, 1990;
Mohamad Tajuddin, 2007). Amongst the sampled texts, A. Ghafar (1999) was exemplary due to his methodical reference to formal elements and characteristics of mosques in investigating the development and variations of mosque styles. It ought to be noted that the works of Abdul Halim and Mohamad Tajuddin - including their extensive body of works related to architecture - are frequently referenced in the 50 initially identified texts on 
Malaysian mosques. This can be attributed to the original and pioneering works that they both produced on mosques and Malaysian or Malay architecture, design and culture.

\subsubsection{Aim of Work}

The aim of these texts was to highlight the development of mosque architecture in Malaysia by identifying, documenting, analysing, and narrating the history of mosque architecture using examples of local mosques. However, Abdul Halim's 1995 book is notable since it included both iconic and lesserknown mosques, thus making it a unique and invaluable record of mosque designs at the time. Furthermore, Mohamad Tajuddin (2007) and Yeang (1992) contextualised their works by including brief discussions on economic, political, ideological and cultural settings of Malaysian mosque architecture.

\subsubsection{Outcome of Work}

Overall, all the authors presented descriptive studies on the history and development of mosques in Malaysia, with more critical analyses observed in the works of A. Ghafar (1999), David Mizan (1990), and Mohamad Tajuddin (2007). There is a strong preference for a chronological approach, which is presented as 3 distinct periods and used as the basis of accompanying discussions on stylistic classes. These 3 period-styles can be generally classified as i) traditional / vernacular, ii) colonial / western, and iii) modern / contemporary. This is translated in all 7 texts which focused on the British colonial period and highlighted the impact of colonialism on the design of local mosques during and after that period. However, there are 2 variations of this tripartite division. Abdul Halim (1984a, 1984b) referenced only 2 stylistic classes in his text, divided into traditional Malay roof form and non-traditional roof form. On the other hand, Mohamad Tajuddin (2007) identified 7 stylistic classes, grouped into Traditional Vernacular, Sino-Eclectic, European Classical, North Indian, Modern Vernacular,
Modernistic and Post Modern Revivalism. The link between style and culture and its influence on mosque development was particularly stressed by David Mizan (1998a) in reference to the Indian Muslim community, and Abdul Halim with regards to the Malays and the Malay monarchies.

Another unique contribution of Abdul Halim in his texts was the use of Indo-Malay architectural and design terminologies to describe local mosques. This is consistent with his interest on geo-cultural boundaries in narrating mosque history, as seen on his emphasis of Peninsular Malaysian mosques (Abdul Halim, 1984a, 1984b) and the IndoMalaysian Archipelagic mosques (Abdul Halim, 1995). Otherwise, all the other texts followed the widely accepted definition of modern Malaysia to include Peninsular Malaysia and East Malaysia. To establish mosques as a distinct building type, David Mizan (1998a, 1998b, 1998c) and Mohamad Tajuddin (2007) defined them through a set of formal elements and characteristics. This is consistent with the definition of type by Pevsner (1997) as bound by function, planning, style, and materials. Thus, it can be said that all 5 authors structured their works based on a combination of period, style, culture, geography, and type.

\subsection{FORMAL ELEMENTS AND CHARACTERISTICS}

From the previous analysis of research approach, it was evident that the descriptions of mosques by these authors referenced a variety of formal elements and characteristics of mosque designs. Thus, a total of 50 formal elements and characteristics were indexed from the 7 selected texts. These were grouped into 5 categories as follows: typological element, spatial organisation, roof form, building technology, and design articulation (see Table 2).

Table 2 : 5 categories comprising 50 formal elements and characteristics commonly found in Malaysian mosques

\begin{tabular}{cl}
\hline $\begin{array}{c}\text { Typological } \\
\text { Element }\end{array}$ & $\begin{array}{l}\text { Prayer Hall; Orientation (Qibla, saf); Mihrab; Minbar; Minaret / Tower; Ablution } \\
\text { Pool; Beduk/taboh \& kerentung. }\end{array}$ \\
\hline $\begin{array}{l}\text { Planning (general); Dimension; Plan (geometry); Plan (layout); Wall (general, } \\
\text { Qibla); Screen; Floor (raised, plinth); Column; Fenestration (door, window); } \\
\text { Organisation }\end{array}$ & $\begin{array}{l}\text { Verandah; Furniture; Fixtures; Covering (prayer mat, carpet); Ceiling; Entrance } \\
\text { (portal); Arcade / Colonnade; Courtyard; Fence; Landscape / Setting; Cemetery / } \\
\text { Mausoleum. }\end{array}$ \\
\hline
\end{tabular}




\begin{tabular}{cl}
\hline $\begin{array}{c}\text { Roof } \\
\text { Form }\end{array}$ & $\begin{array}{l}\text { Pitched Roof (gable, hip); Pyramidal Roof; Dome; Roof Variant (flat, folded } \\
\text { plate, cone etc.); Roof Ridge; Roof Eave; Finial. }\end{array}$ \\
\hline $\begin{array}{c}\text { Building } \\
\text { Technology }\end{array}$ & $\begin{array}{l}\text { Construction Technology (traditional etc.); Structural Systems; Building } \\
\text { Materials (natural, manufactured); Finishes; Craftsmanship. }\end{array}$ \\
\hline $\begin{array}{c}\text { Design } \\
\text { Articulation }\end{array}$ & $\begin{array}{l}\text { Aesthetics (general); Style; Pattern; Calligraphy; Sculpted Element (carvings, } \\
\text { mouldings etc.); Column Order; Colour; Symbolism (cosmology, metaphor); } \\
\text { Image (house, palace etc.); Composition (façade, interior elements); Scale. }\end{array}$ \\
\hline
\end{tabular}

In this paper, typological element is considered as unique design elements of mosque architecture that differentiate them from other building types, and spatial organisation is defined as functional and typical architectural elements that are organised to allow a mosque to function as such. Additionally, roof form is allocated its own category due to the considerable impact they have on local mosque designs as implied by all 5 authors, while building technology includes all aspects related to structures and materials. Finally, design articulation is the design expression of a mosque that goes beyond functional or liturgical requirements in order to beautify the structure and/or convey symbolic meanings. From the list, it is clear that there are uneven distributions of elements and characteristic amongst the categories. However, these categories overlap with each other to a certain degree, such as the mihrab which can be viewed as both a typological element as well as part of the Qibla wall under spatial organisation.

From the 5 categories, roof form is consistently referred to by all 5 authors. Multi-tiered pyramidal roofs and domes were described based on their profiles, configurations, ornamentation, construction, and materials. The various references and discussions on roof forms suggest that they are an important feature of local mosques, above and beyond references to other formal elements and characteristics such as minarets and interior planning. Furthermore, roof form seemed to be strongly associated with the design articulation category; together, their variations and combinations defined the different styles of local mosques. These roof forms are differentiated by their contexts, such as geo-cultural regions found in Malaysia (e.g. Melaka or East Coast mosque roof forms) and IndoMalaysian Archipelago (e.g. Javanese, Sumatera, Pattani). Thus, all of these elements and characteristics are fundamental to any studies wishing to holistically describe mosque architecture in Malaysia, enabling detailed narratives of mosque designs, histories and developments.

\section{DISCUSSION}

There are 3 aspects which materialized from the analysis of the selected texts, which could prove to be of use to current and future research on local mosque architecture.

\subsection{UNIQUE ELEMENTS AND CHARACTERISTICS OF MOSQUES IN MALAYSIA}

The 50 identified formal elements and characteristics were subsequently analysed by crossreferencing with other texts on local mosques. Accordingly, a combination of 9 elements and characteristics emerged that may be considered unique to traditional Malaysian mosques:

i. Beduk/taboh \& kerentung: Beduk/taboh (drum) and kerentung (wooden bell) are implements to call for prayers.

ii. Square floor plan: This can be traced to pre-Islamic Hindu Buddhist design influence of the region, and almost exclusively used in traditional local architecture either as religious structures or small pavilions (wakaf).

iii. Raised floor on posts: Part of the Austronesian building tradition in which buildings are elevated from the ground for practical and symbolic purposes.

iv. Verandah (serambi): A climatic response to protect the main prayer hall, as well as a transition space which also separates formal and informal activities within the mosque.

v. Principal columns (tiang seri): These are interior columns typically arranged in groups of 4 to support the top tiers of multitiered pyramidal roofs. They are similar to 
the soko guru found in traditional Indonesian mosques.

vi. Multi-tiered pyramidal roof (bumbung limas): Pyramidal roofs, usually in tiers of 2 or 3 , are a logical extension of the square floor plans due to their complementary geometries. The upper tiers of a pyramidal roof typically cover the main prayer hall while its lowest tier sometimes extends over the verandah.

vii. Traditional construction technology: Building structures and joineries are the result of traditional tools and practical building solutions which were refined by local craftsmen.

viii. Building materials: Indigenous building materials found in the Indo-Malaysian Archipelagic region such as timber, bamboo, clay and stone shaped the designs of local mosque architecture.

ix. Composition of façade and interior elements: The combinations and proportions of the different architectural elements of local mosques - as seen on the exterior and interior - set it apart from other mosques in the Muslim world.

All in all, the 5 authors utilised most, if not all, of the 9 elements and characteristics to describe the designs of early local mosques. However, due to the shared history of Malaysia and Indonesia, these formal elements and characteristics are equally relevant to early mosques from both countries.

\subsection{AMBIGUITY}

In this paper, the issue of ambiguity is divided into language, conceptual, and factual ambiguities. Language ambiguity refers to the complexity of architectural terminologies in mosque designs due to overlapping Arabic, Malay, Indonesian, and English terms. This can be partially traced to the common cultural roots of the Indo-Malaysian Archipelago which meant comparable and interchangeable use of Indonesian and Malay terms to describe the same architectural feature. Case in point is the reference to the multi-tiered pyramidal roof by Abdul Halim (1995) who used the terms bumbung limas, bumbung bertingkat, bumbung meru, and atap tumpang, among others; it is possible that these referenced variations of multi-tiered pyramidal roofs specific to a particular region, period, or style.
Another language ambiguity comes from the usage of Malay vernacular terms. An example is the English translation by Abdul Halim (1984b, p. 69) of the local nickname of Masjid Batu for the AlMuhammadi Mosque in Kelantan as the Brick Mosque. However, Abdul Halim have also accurately used the term batu bata (1995, p. 59) to refer to bricks $(2004$, p. 60). This shows that the author have faithfully reflected the Malay vernacular terms associated with batu (lit. stone) which could mean stone, clay bricks or cement blocks, particularly when discussing masonry construction.

Conceptual ambiguity refers to a historian's attempt to define the conceptual parameters of a research. A key example is the definition of Malaysia, which is a contemporary geo-political entity which officially came into existence in the twentieth century. But as can be seen in Table 1, in discussions on Malaysian mosques, most included examples from Sabah and Sarawak, although a few authors such as David Mizan (1990) and A. Ghafar (1999) focused only on mosque samples from Peninsular Malaysia only. For the latter, it could be argued that to investigate the history of mosques in Malaysia would necessarily mean emphasizing Peninsular Malaysia with its history of Islamisation and the early role of the Malay Sultanate of Melaka. But to be thorough, there ought to be an additional consideration of the fluid boundaries that were present in the Indo-Malaysian Archipelago, a factor highlighted by Abdul Halim (1995). Hence, a study of early mosques in Malaysia could also entail other early mosques of the region so that a balanced and a clearer understanding of their evolution is possible.

Likewise, discussions on styles and their relationship to a historical timeline are left undefined in the majority of the selected texts. This is particularly evident in the use of the term vernacular style which some have used to refer to both eighteenth and twenty-first century mosques. A solution was proposed by Mohamad Tajuddin (2007) who introduced the terms traditional vernacular and modern vernacular styles. However, even the terms vernacular and traditional were sometimes used interchangeably by some authors. Perhaps this led A. Ghafar (1999) to make the distinction that the term vernacular refers to a style whereas traditional is considered more of an influence. Additionally, the difference is defined by Rapoport (1969, pp. 5-6) in that vernacular is a 
pragmatic approach to design which is flexible in its response to contexts and lack theoretical or aesthetic pretensions, whereas traditional refers to a characteristic that values an ideal model of a design and is the culmination of the collaboration between craftsmen, builders, and users over generations.

Lastly, factual ambiguity is persistent within this field since certain facts such as dates, patrons, and builders - particularly when referring to lesser known mosques and/or early mosques - are difficult to be fully substantiated. The lack of contemporaneous documentation on early mosques could be attributed to the inability of early Malay societies to develop a widespread writing system (Mohd Arof Ishak, 2007, p. 158), thus partially contributing to the poor documentation of the region's Islamic architecture (Michell, 2006, p. 279). Unfortunately, factual ambiguity remains true for a number of early and middle twentieth century mosques as well. This is an unfortunate trend since elements such as roofs, floor plans, and finishes can change within the lifespan of a mosque. Therefore, without documentation of when, why, or how they changed, the history of Malaysian mosques is left incomplete.

\subsection{COMPLEXITY OF CLASSIFICATIONS}

In the span of a little over 50 years, from the completion of the Mughal-inspired Kuala Lumpur Jamek Mosque in 1909 to the opening of the modernist National Mosque in 1965, the bold experimentation with architectural styles of Malaysian mosques demands a closer look at the way it has evolved. In investigating the history of mosques in Malaysia, the identification of architectural styles is a useful and often-used approach. This is frequently divided into the 3 period-styles previously mentioned, which is often viewed as being chronologically sequential. Thus, the attempt by Mohamad Tajuddin (2007) to expand the classification of mosque styles into 7 distinct groups from the often-used 3 groups is particularly useful (see Figure 1). This diagram (which is an interpretation by this paper's authors' based on Mohamad Tajuddin's work) showed his consideration of the substantial overlaps between the categories when compared chronologically. This also shifts the focus to the formal elements and characteristics of local mosques that can be considered unique to each style.

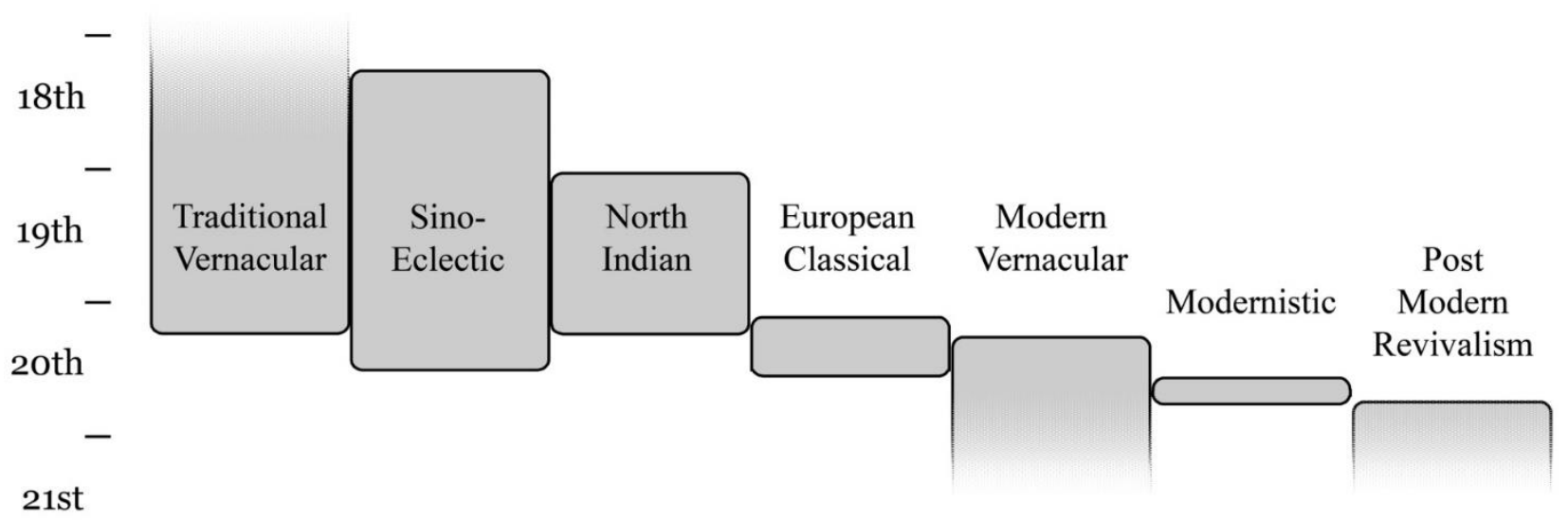

Figure 1: Diagram showing stylistic classification of mosques and their historical timeline based on extant mosques in Malaysia. Original classification by Mohamad Tajuddin (2007). 
That being said, it can also be observed that mosque architecture in Malaysia has formal characteristics that may not fit easily into any one class. Case in point is the Melaka traditional mosques which were classified as Sino-Eclectic style by Mohamad Tajuddin (2007), Melaka style by David Mizan (1990) and Yeang (1992), part of the Southeast Asian great mosque style by David Mizan (1998b), traditional style with regional influence by A. Ghafar (1999), and Malay World style by Abdul Halim (1995). This hybridity of Malay, Chinese and Western designs layered over a period of time is stylistically challenging, as illustrated by the Tengkera Mosque in Melaka (see Figure 2).

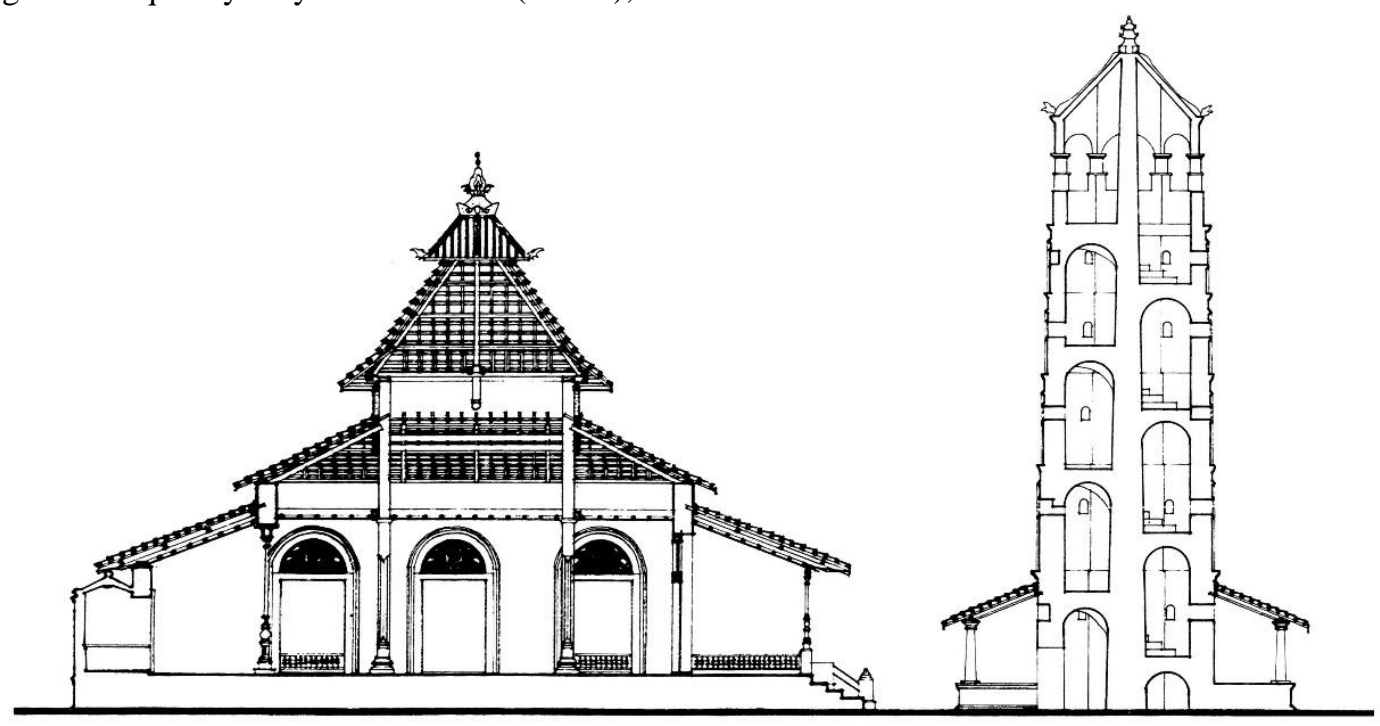

Figure 2: Sectional drawing of the Tengkera Mosque, Melaka built in the eighteenth century. Measured drawing by Mohd Suhaimi, Saleha, Poongavanam, Abu Hari, and Mohd Ali (1981).

In this mosque, the three-tiered pyramidal roof, square plan and overall proportion are typical of traditional timber mosques of the region, while the roof ornamentation and pagoda-inspired minaret display Chinese influence. In turn, the columns, arched doorways and balustrades can be traced to Western architectural styles. This one example raises the question of whether classificatory system can ever adequately address the complexity of multiple design influences found in local mosques. A useful approach by Watkin (2005, p. 7) suggested that these classification should be used carefully and judiciously to emphasize "a living continuity rather than a museum of styles, a garden rather than a cemetery", which is echoed in Mohamad Tajuddin's classification.

Another effect of stylistic-based classification is the tendency for a monolithic approach to studying mosque architecture by the 5 authors. For example, a British colonial era mosque might be described as being neoclassical or Art Deco i.e. analysed as a single design entity, but this might overlook the various formal elements that make up the mosque, each with its own developmental history when compared collectively with other local mosques. Investigations into how these formal elements are combined and their significance might reveal new findings and alternative perspectives on the subject matter. An acknowledgement of this potential can be interpreted from David Mizan (1990) who hinted at the evolution of local mosques based on selected design components such as those related to spatial organisation and roof form, and from Abdul Halim (1995) who gave detailed explanations of the various traditional roof forms of the Indo-Malaysian Archipelagic mosques.

\section{CONCLUSION}

Though initially limited to inventories and descriptive studies, the historiography of mosque architecture in Malaysia has expanded to more critical analyses of mosques. This has positioned mosques as a significant building type in Malaysian architecture as well as recognising them as important repositories of local culture, ideology, and history. From an examination of selected works of 5 authors, it was determined that the general research 
approach found within this area is strongly dependent on a combination of chronological, stylistic, cultural, geographical, and typological approaches. Most follow a division of period-style typically interpreted as traditional / vernacular, colonial / western, and modern / contemporary, although there have been some proposals to re-examine and expand this division. These approaches were further defined through the use of formal elements and characteristic, of which 50 were subsequently identified. Consistently used to describe the wide variety of mosques found in Malaysia, these elements and characteristics were grouped into 5 distinct yet overlapping categories of typological element, spatial organisation, roof form, building technology, and design articulation. These categories could be potentially used to holistically narrate the history and development of local mosque designs by bringing into focus the parallel and overlapping developments of each category, as well as the formal elements and characteristics within. At the same time, it also strengthens the link between the history and development of mosque architecture in Malaysia and the evolution of general Malaysian architecture.

From this study, 3 significant aspects emerged. The first is a proposed set of 9 formal elements and characteristics that could be considered unique to traditional Malaysian mosques. These were identified as i) beduk I taboh \& kerentung, ii) square floor plan, iii) raised floor on posts, iv) verandah (serambi), v) principal columns (tiang seri), vi) multi-tiered pyramidal roof (bumbung limas), vii) traditional construction technology, viii) building materials, and ix) composition of façade and interior elements. These are worthwhile to be examined indepth and perhaps reimagined into contemporary mosque designs. The second aspect is related to the problem of ambiguity categorised as language, conceptual, and factual ambiguity. Each has indirectly or directly affected studies on local mosque architecture, and may be largely attributed to the diversity of culture and beliefs found in this region and the lack of documentation of mosques, particularly the early ones. The third and final aspect is related to the use of classification as a research tool or strategy which needs to be judiciously employed. Classifications should reflect the complex, multifaceted yet subtle conditions of mosque development in Malaysia, particularly with contemporary design inspirations coming from considerations of sustainability, globalisation, and expansion of the role of mosques in contemporary society. Thus, it is hoped that future studies on mosque architecture might clearly respond to these aspects embedded within the discourse on local mosque architecture.

\section{REFERENCE}

A. Ghafar, A. (1999). The Architectural Styles of Mosques in Malaysia: From Vernacular to Modern Structures. Paper presented at the Symposium on Mosque Architecture: The Historic and Urban Developments of Mosque Architecture, Riyadh, Saudi Arabia.

Abdul Halim, N. (1984a). Masjid-masjid di Semenanjung Malaysia (T. Mohd. Ridzuan \& A. B. Ahmad Sebi Eds.). Kuala Lumpur: Berita Publishing.

Abdul Halim, N. (1984b). Mosques of Peninsular Malaysia (T. Mohd. Ridzuan \& A. B. Ahmad Sebi Eds.). Kuala Lumpur: Berita Publishing.

Abdul Halim, N. (1995). Seni Bina Masjid di Dunia Melayu-Nusantara. Bangi, Selangor, Malaysia: Penerbit Universiti Kebangsaan Malaysia.

Abdul Halim, N. (2004). Mosque Architecture in the Malay World (Omar Salahuddin Abdullah,
Trans.). Bangi, Selangor, Malaysia: Penerbit Universiti Kebangsaan Malaysia.

Abdullah, M. (1978). Bentuk-bentuk Bangunan Masjid: Kunci Memahami Kebudayaan Melayu Kuala Lumpur: Kementerian Kebudayaan, Belia dan Sukan Malaysia.

Al-Faruqi, I. R., \& Al-Faruqi, L. L. (1986). The Cultural Atlas of Islam. New York, NY: Macmillan.

Alice Sabrina, I. (2008). The Influence of Islamic Political Ideology on the Design of State Mosques in West Malaysia (1957-2003). (Doctor of Philosophy), Queensland University of Technology, Brisbane, Australia.

Armani, S. (2014). The influence of Chinese architecture on traditional Melaka Mosques. (Masters), University of Malaya, Kuala Lumpur. 
Bruce, A. (1996). Notes on Early Mosques of the Malaysian Peninsula. Journal of the Malaysian Branch of the Royal Asiatic Society, 69(2 (271)), 71-81. doi:10.2307/41493308

Cortesão, A. (Ed.) (2005). The Suma Oriental of Tomé Pires: An Account of the East, from the Red Sea to China, Written in Malacca and India in 1512-1515, and The Book of Francisco Rodrigues, Rutter of a Voyage in the Red Sea, Nautical Rules, Almanack and Maps, Written and Drawn in the East Before 1515 (Vol. II). New Delhi, India: Asian Educational Services.

David Mizan, H. (1990, Nov/Dec). Typology and the Evolution of the Malaysian Mosque. Majalah Akitek, 2, 70-82.

David Mizan, H. (1998a). Indian and Mogul Influences on Mosques. In V. F. Chen (Ed.), The Encyclopedia of Malaysia: Architecture (Vol. 5, pp. 84-85). Singapore: Archipelago Press.

David Mizan, H. (1998b). The Southeast Asian Great Mosque. In V. F. Chen (Ed.), The Encyclopedia of Malaysia: Architecture (Vol. 5, pp. 42-43). Singapore: Archipelago Press.

David Mizan, H. (1998c). Western and Modernist Influences on Mosques. In V. F. Chen (Ed.), The Encyclopedia of Malaysia: Architecture (Vol. 5, pp. 86-87). Singapore: Archipelago Press.

Frishman, M., \& Khan, H.-U. (Eds.). (2007). The Mosque: History, Architectural Development \& Regional Diversity. London, UK: Thames \& Hudson.

Michell, G. (Ed.) (2006). Architecture of the Islamic World. London, UK: Thames \& Hudson.

Mohamad Tajuddin, M. R. (2007). Mosque Architecture in Malaysia: Classification of Styles and Possible Influence. Jurnal Alam Bina, 9(3), 1-37.
Mohd Arof Ishak. (2007). The Malay Civilization. Kuala Lumpur: Persatuan Sejarah Malaysia.

Mohd Suhaimi, R., Saleha, M. A., Poongavanam, S., Abu Hari, H., \& Mohd Ali, O. (1981). Masjid Tengkera, Bandar Melaka, Melaka. (Undergraduate Measured Drawings Report), University of Technology, Malaysia, Johor, Malaysia.

Pevsner, N. (1997). A History of Building Types (Vol. 19). New Jersey, NY: Princeton University Press.

Rapoport, A. (1969). House Form and Culture. Englewood Cliffs, NJ: Prentice-Hall, Inc.

Rosniza, O. (2011). Mihrab Design and Ornamentation of Selected Mosques in Malaysia. (Doctor of Philosophy), University of Malaya, Kuala Lumpur, Malaysia.

Rosniza, O., Nila, I., \& Yahaya, A. (2008). A Typological Study of Mosque Internal Spatial Arrangement: A Case Study on Malaysian Mosques (1700-2007) Journal of Design and Built Environment, 4(1), 41-54.

Vlatseas, S. (1990). A History of Malaysian Architecture. Singapore: Longman.

Watkin, D. (2005). A History of Western Architecture (4th ed.). London: Laurence King Publishing.

Yeang, K. (1992). The Architecture of Malaysia. Kuala Lumpur, Malaysia: The Pepin Press.

Yulianto, S. (2000). Arsitektur Mesjid dan Monumen Sejarah Islam. Yogyakarta, Indonesia: Gadjah Mada University Press.

Zakiah Hanum. (1981). Senibina Kebangsaan Kajian dan Dokumentasi. Paper presented at the Seminar Kearah Identiti Kebangsaan Dalam Senibina, Kuala Lumpur. 